\title{
1-1 チャの花器の耐凍性とその品種間差異
}

筑瀬好充・武田善行・近藤貞昭

（農林水産省茶業試験場 枕崎支場）

品種育成のために交配を行 万場合，日本種は開花時期 が早いので涷害の心配はないが，新しい香気や耐病性の 導入のためにアッサム種と交配をはかる場合は，開花期 が12月に入るため, 花や幼果の耐凍性が交配の成否に影 響を及济すと考光られる。しかし現在のところ，チャの 花器の耐凍性についての知見は乏しいので，まず花器の 器官別耐凍性と品種間差異を中心に榆討を試みた。

やぷきたを含む日本種 6 品種，アッサム雑種拉よびア ッサム種について, $-2{ }^{\circ} \mathrm{C} \sim-5{ }^{\circ} \mathrm{C}$ で 2 時間の低温処理 を行ったところ, 花器の耐凍性は成葉や冬芽に比べてか

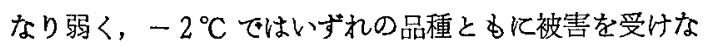
かったが， $-3{ }^{\circ} \mathrm{C}$ ては花系の一部被害を受け， $-4{ }^{\circ} \mathrm{C}$ では花系, 䒺, 花柱, 子房に被害がみられ, 品種によ二

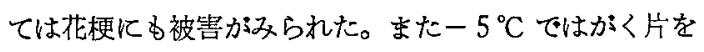
除いて, 汪とんどの器官が壊死したが，花粉は全く健全 で, 発芽力も十分維持された。

花器の成熟度と耐凍性との関保をみると，開花前日〜 数日前の大蕾の酎凍性が最もまさり，開花したものは花 柱が被害を受けやすく，また末熟な小蕾は耐凍性が最も
弱かった。

開花が終って受精されたるのは花梗の耐凍性が急速に 強化され，子房の耐凍性るまさったが，さらに幼果の発 育が進み 8〜10 $\mathrm{mm}$ に肥大したるのは逆に耐凍性が低 下する傾向を示した。

花器の利凍性の品種間差異をみると，枝幹や成葉にみ られるよ5な大きな差異はないが，日本種ではやぶきた ややまと爻どりがやや強く，や兄注は弱い傾向を示し， ベにたちわせ，Ak 1699 等アッサム雑種やアッサム種は 弱く, 一般的な品種の耐凍性の強弱と医恬同様の傾向を 示した。

また，成葉や冬芽の耐凍性は冬季の気温の低下にした がって耐凍性を著しく増すが，花器についてはこのよう な Hardening は比較的少なかった。

以上の結果から, 花器の低温障害はー $3{ }^{\circ} \mathrm{C}$ 程度でも起 るのて，交配可能期間は一応初霜期むでと考兄られた。 な拉，凍害を防ぐことができる温室やガラス室内では， チャの花芽分化が 連続的に晚秋まで行われることを利用 して，翌春まで交配を続けることも可能と考党られる。

\section{$1-2$ 新香気緑茶品種育成のための素材の検索}

筑瀬好充・武田善行・近藤貞昭・家弓実行

（農林水産省茶業試験場 枕崎支場）

鳥屋 尾忠之

（農林水産省茶業試験場）

今後の茶の消費拡大と赀好の多樣化に 対応するために は，今まてのやぶきた型の香気ばかりでなく，るっと特

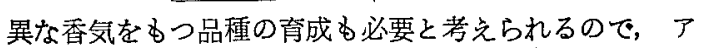
ッサム種, アッサム雑種, 中国種等の㕕範な保存系統の 中から，好をしい香気をるつ菜材を検索し，育種への利 用を検討した。

当場に保存・育成中の大量の個体群から，特徵のある 有望香気をるつ個体を検索する方法として，蒸桬直後に 宫能的に織別する方法るかなり有効であり，投入量 $50 \mathrm{~g}$ の微量製茶機て 製茶したすのの官能審查と併用すること により，検索の効率化が仙れると考党られた。

これらの結果, 当場保存個体群の香気の特徴は多岐に
わたり，バラの花香，かんきつ香のような花や果物の香 気に近いるのから，エンドウ臭やイモ臭のよ5なあまり 好ましくないるのまでみかり，一応有望と考市られた ものはアッサム種 582 系統中 22個体，中国種 174 系統中 44 個体が多いだされた。

有望と判定された個体の香気をその特徴別に分類する と，A，B，C，D，の4群に大別でき，Aは Ak1699， Boh 71 代代表 される花香， B は Ak 1440 やND 113 に代表される清香， C は Cp 13 p $\mathrm{Ck} 16$ に代表される中 国茶風の香気，D はやぶきたに代表される日本緑茶の香 気である。

これらの香気の特徵と 茶樹の分類との関係をみると， 


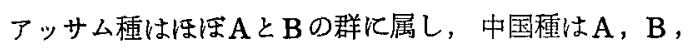
C，Dいずれの群にも属するるのがあった。また，香気 の分類と水色や滋味との関係をみると， AやBの群はC やDの群に比べて評点が少る㑯向が文られた。

印雑 131 や $\mathrm{p} 13$ は香気の特徵がかなり明確であり, 容易に判別でるのて，これらとやぶきたとの交雑後代 $\mathrm{F}_{1}$ について，親の香気に対する近似性を検討したとこ ろ，印雑 131 や $\mathrm{Cp} 13$ の香気を検知できるすのと，でき
ないあのとの比率はほぼ：1であり，検知できるすの についてそれを強, 中, 弱に分けると，その比率は拈 よそ1：1：1であった。

またこれら $\mathbf{F}_{1}$ の香気の近似程度と品質評点との間に は一定の傾向は認められなかった。

したがって，特定の香気を他の品質要因をてこならこ となく，新品種に導入することは比較的容易と考えられ た。

\title{
1-3 チャの交配組合せとその後代の品質について
}

武田善行・筑瀬好充・近藤貞昭・家弓実行

(農林水産省茶業試験場 枕崎支場)

鳥屋尾忠之

（農林水産省茶業試験場）

松下繁

（農祄水産省知覧茶原種農場）

新品種育成のためにこれまで 各試験研究場所で多くの 交配か行われてきているが，交配組合せと後代の品質と の関係については活とんど報告がない。をこで茶試枕崎 支場に打いて 1968 年から 75 年までに行ったアッサム雑 種を含む各種交配組合せの中から，1組合せ当り20個体 以上の品質調查を行ったことのある 43 組合せを抽出し て, 交配組合せと その後代の品質との関係を水色と滋味 の面から検討した。なおここでは相反交雑のある組合 せは同一組合せとして扱い，また二・三番茶は夏茶とし てまとめて扱った。

各組合せごとの平均值に打ける水色と滋味の関係で は，一番茶では両者の間保 $\mathrm{r}=0.651^{* *}$ のかなり高い正 の相関が認められたが，夏茶ではこの関係は明りょうで はなかった。をた各組合せごとの水色と滋味の平均值は 一般に両親の平均値（平均親）上りも低かった。親子相 関係数は一番荼では水色で $0.607^{* *}$ 滋味で $0.633^{* *}$ を示 し, 二番茶では滋味で $0.792^{* *}$ と高い值を示したが，水 色ではほとんど相関を認めなかった。

両親の平均值に対する子の回㷌から求めた 回㷌係数 は, 一番茶では水色, 滋味ともに 0.55 前後であったが, 夏茶では両者とも低かった。
このようなことから 各組合せ後代の水色と滋味は一番 茶では両親の平均值からほ压予測できるが，夏茶では難 しいことが推察された。

交配親としてアッサム雑種利用の可能性を考えると， 水色てはアッサム雑種を片親としても特に低下はみられ ず平均 3.17 (2.90〜3.47，29組合せ）を示し，日本種同 士の組合せ（平均 $3.21 ， 3.03 \sim 3.43 ， 15$ 組合せ）と明り よらな差異は認められなかった。

滋味はアッサム雑種を片親とした組合せでは苦味が強 いものから優良な組合せをであり（平均 $2.87 ， 2.40$ $3.22,31$ 組合せ), 日本種同士の組合せ (平均2.94, 2.55 〜3.19, 16 組合せに).比べて変異が大きかった。

交配親としてみると，日本種ではやぶきた，あさつゆ， くりたわせに良いものが多く，アッサム雑種では $F_{1} 278$

(鹿 Ch $2 \times \mathrm{Ai} 105$ )， G 343 (Ak 自然実生)， $F_{1} 10123$ ( $F_{1} 288 \times$ べにたちわせ)，ささつまべに等が優れる傾向 を認めた。

このようなことからアッサム雑種は耐病性だけでなく 品質面においても充種素材として十分利用できる考克 られた。

\section{1-4 低温での新芽の被害の品種間差異}

\author{
倉 貫 幸 一
}

（静岡県茶業試験場）

凍籍害は，一夜にして茶農家に大きな損害をるたらす が，その対策としては，防霜ファン，被覆による予防的
な方法と晚生品種の導入による回避がある。るし聇霜性 飞生理的なるのが存在するなら, 而霜性品種の青成も可 
能であると考兄られる。一方，品種については，ほ場で の被害程度の違いや被害後の回復力の違いについての調 查があり，差が認められているが，湯での被害発生は 条件が一様でない場合が多い。そこで, 萠芽期前後 3 回, 淂場方材料を採取し，低温槽内で $-2.6^{\circ} \mathrm{C} と-3.6$ ${ }^{\circ} \mathrm{C}$ 程度の温度で弅理を行った。観察は芽李たは新芽の葉 を解剖して行った。

その結果, 萌芽期前の $-3.6^{\circ} \mathrm{C}$ の処理では, 被害芽率 でや充ほが低く，心の枯死率とグレード平均で括狲いわ 巳，やまかいが高く，や充汪が低かった。

萌芽期頃の処理で，被害芽率については $-2.6^{\circ} \mathrm{C} て ゙ ，$ かなやみどりが低く， $-3.6^{\circ} \mathrm{C}$ てさやまかおりが低かっ た。心の枯死率については $-2.6^{\circ} \mathrm{C}$ で差はなかったが， $-3.6^{\circ} \mathrm{C}$ でや充深が高く，さやまか找りが低かった。グ

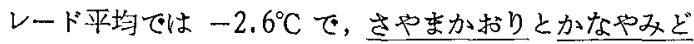

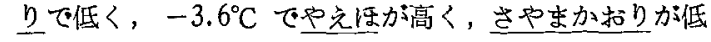
かった。

一・二葉期頃の 処理て，被害芽率们つては $-2.6^{\circ} \mathrm{C}$

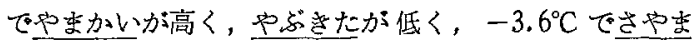

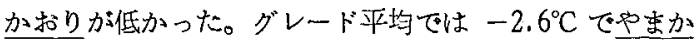

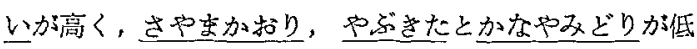

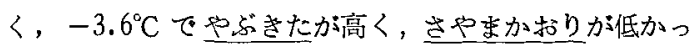
た。

以上のことから， $-2.6^{\circ} \mathrm{C}$ の処理では被害の発生が低 く, 品種閒の差は著しくないが， $-3.6^{\circ} \mathrm{C} て ゙ は$ 低温に対 する被害の発生の仕方化差か認妨れ，荫芽期頃加ら一 二葉期頃に茶芽の低温に対する生理的な面の品種閒の抵 抗性の差か存在するすのと考光られ，さやまか打りが供 試した他の品種に比べ強いことがわかった。

\section{1ー5 チャの毛茸の密度, 形態の品種間差 \\ 安間舜 \\ （農林水産省茶業試験場）}

演者はチ十の栄養体の微細構造や化学成分によって品 種の識別が可能かど5かを検討中である。ここではチャ 幼葉の裹面汇着生する毛茸の有無, 密度, 形態等保種 間差があることがわかったので報告する。

\section{材料と方法}

供試品種はアッサム種, 中国種, 台湾種, 台湾やまち やおよびアッサム雑種の48品種・系統である。三番茶芽 の摘採適期の第1葉を採集し，セロテープを葉の裏面へ 押しつけて毛茸をはぎとり，そのセロテープをカバーグ ラスの代りとしてスライドグラス上へ貼付した。

検鏡部は葉の中央附近の中肋の両㑡とした。各品種 5 枚について毛茸の有無, $10 \times 10$ 視野内の毛莗数, 最長毛 茸長，細胞質の未後退部分（若い毛茸の内部には細胞䆩 が充満しているが，老化するとそれが先端から基部へ向 って消失し，細胞壁のみとなる)の長さを調查した。

結果と考察

毛茸の有無 台湾やまちゃは供試 3 系統とす毛茸は認 められなかった。アッサム種は葉の全面にはなく，中肋 附近だけ江着生するるのが多かった。全面仙着生して いない系統はダージリン座茶樹, 台汾種, 中国䨪に諗め られた。今回調査した日本種，アッサム雑種はすべて全
面に着生が認められた。

着生密度 全く認められない台湾やまちゃから $10 \times 10$ 視野内に 75 本も着生する台湾種の“蒔茶”まで著しく変 異に富む。アッサム種は密度が低い傾向があった。日本 種, 中国種, 台湾種, ダージリン産茶樹はそ机らのグル 一プ内でる，極めて変異が大きかった。たたしこの密度 は葉面積の生長と関係があるので，密度の調查法につい ては検討の要がある。

長さ 極めて変異に富み,アッサム䅉の Aboll の350 $\mu$ から U21の $1000 \mu$ までり，同一産地の系統間にも 大きな変異があった。アッサム種, 台湾種は短い傾向が あった。

細胞質の未後退部分の長さアッサム種や台湾種は早 く後退して絧胞壁の肥厚が早く，中国種，日本種は逆に 扣そく, その他のグループは変埋が大きかった。の現 象と炭そ病抵抗性との関係はすでに浜耊が指摘してい る。

以上のよ5に毛苜の有無, 密度, 長さ, 毛称内部の細 胞質の後退の早さなどに大きな品種閏差があることがわ かり，チャ幼葉の毛贲は品種の識別に利用できる見通し を得た。

\section{1-6 寒冷地における㨂木時期の体系化（第 1 報）}

一春插に捛ける年内生長一

\section{内 野 博 司 \\ (埼玉県茶栄試験場)}

埼玉県に抬ける茶苗木の生産は，夏捜が慣行的に行わ れているが, 次の点て問題がある。1専用母樹園の確保 
2 挿木期間の限定 3 育苗期間の長さ。これらの点を解 決するため，挿木時期に関する試験を行い，春挿につい ては一応の結果を得られたので報告する。

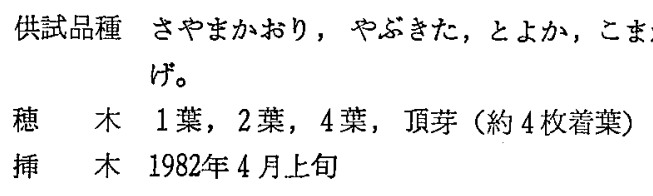

挿木方法密閉㨂，插床は，黒のポリマルチを行っ た。穂間隔 $3 \mathrm{~cm}$ (または $4 \mathrm{~cm}$ ) 条間 18 $\mathrm{cm}, 3$ 反復。

12月に，1区10本を掘取り調查し，慣行の夏括 1 年生 及び 2 年生苗と比較した。以下, 生育の最もよかった さやまか打りを中心記す。

生存率及び健全苗率は，頂芽がやや少るもの0全般に かなりよかった。重量, 幹径, 根径及び $\mathrm{T} / \mathrm{R}$ 率は, 插 穂葉数の増加に伴、増加し，夏㨂 1 年生と 2 年生の中間
の值を示した。分枝数は，1，2，4葉の順で多かった。 また頂芽の低位置からの分枝は，他の㨀穗からのものよ り多かった。

以上のことより，春捜 1 年生苗木は，夏挿 1 年生苗木 より大きく，翌年春に仮植するには，夏挿 1 年生または 2 年生苗木より適当で，また，插穂 4 樂及び頂芽からの 苗では，一部定植が可能と思われた。おな，こまかげ （2葉と頂芽のみ実施）はさやぬかおりと同様の傾向で あった。やぶきたは，健全苗率 $49 \%$ \%ら $71 \%$ とやや低 かったが，一因として插穂の越冬状態の悪ざが考えられ た。生育状況は，さやまがりと注同じ傾向であっ た。な掠，やぶきたの頂芽からの苗は，1，2，4葉か らの苗に此べると，上根は皆無であった。とよかは，1， 2，4葉からの苗は，健全苗率 30\%以下であったが頂芽 からの苗は，43\%とやや高かった。

春挿 1 年生の生育停止期に拈ける生長量（さやまかおり 57.12 調査）

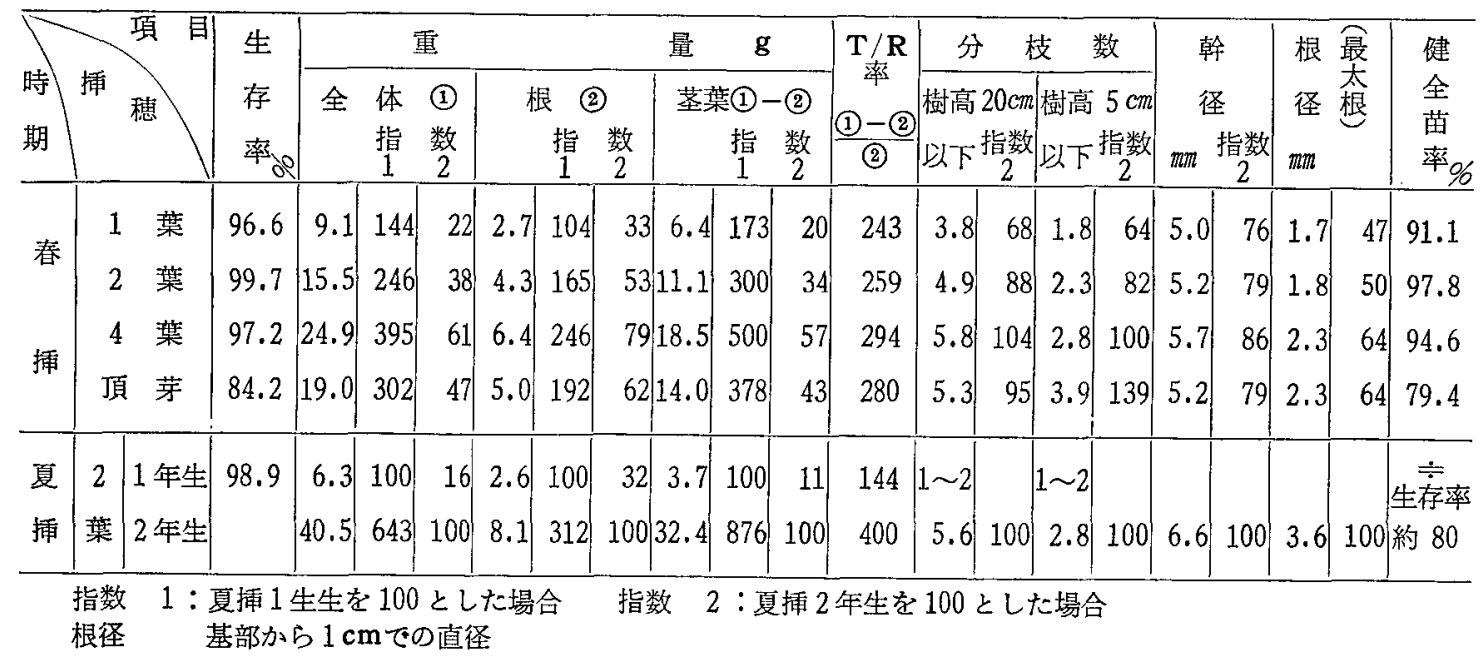

\section{1-7 茶樹の種子を栽培用品種育成の方法論的研究}

1 放射線利用による自家和合性茶樹の検索 (1) 供試材料之検索方法

$$
\begin{aligned}
& \text { 㴊之上康 元 (埼玉等茶業試験場) } \\
& \text { 柾飼保雄 (農丵技術研究所) } \\
& \text { 山口勲夫 (九州農業試験場) } \\
& \text { 北田嘉一(埼玉県茶業試験場) }
\end{aligned}
$$

Lewise \& Crowe (1954) は，オウトウで自家結実性 品種育成を目途にX線を照射した花粉を用いて自殖して 得た実生から pollen-part mutant と思われる自家和 合性変異体を得, その後 Mathews \& Lapins (1967) がこの変異体の花粉を使って “Stella”と命名される自
家和合性の品種を育成した。なおかが国では町田 (1980) が，鳥取県で発見され種苗登録された 自家和合性の梨の “招さ二十世紀”のS因子型を決定し，これを“二十世紀 梨”の stylar-part mutant であるとし，これを交配母 木に供用することにより，交たさらに今後放射線を利用 
することにより pollen or stylar-part mutant を誘 起し，多数の自家和合性の品種を育成できるであろうと 報じている。

一方茶樹の自家不和合性遣伝子の 分析については，す でに湔之上（1969）の報告があり，茶樹がタバコ属，バ ラ科の植物やさきの梨等と同じく， $\mathrm{S}$ 因子は一対の復対 立遺伝子よりなり 配偶子型の遺伝様式をとることを明ら かにし, 主要12品種の因子型も決定済みである。

さて現在放育場にはチャの代表的品種やぶきた $\left(\mathbf{S}_{4} \mathbf{S}_{5}\right)$ の clone よりなる集団茶園のみが存在し，周囲には花 粉樹と目されるすのは極めて少ない現状から，むしこの や忍さた種子が得られるならば，それらの中には S因 子の mutant 江起团した将来自家和合性の茶樹（種子ま
き用品種育成用の母材）となるであろら種子の混在する ことを想定することができよ。

そこで筆者らは 1981 年 10 月に約 3,500粒の自然交配種 子を得，種子調查ならびに 発芽試験を実施したが，その 結果照射國場中の種子は無照射の種子ょりる，(1) 1 株当 り採種数は少なく，(2)不良種子割合も多く，(3)20粒重も 軽い傾向が双られたが，(4)一方発芽率は，は種後 3 力月 目で $86.3 \%$ と概して高く, (6)昨年 1 月現在で 2,549 個体 もの実生を養成中である。

今後，これらの個体について，さきにふれた mutant がどの程度混在するかを明らかれすべく，その検定法に ついて考察した。

\title{
1-8 Camellia 属各種植物における化学成分の種間変異
}

永田忠博・酒井慎介

(農林水産省茶業試験場)

カメリア属各種について チャ品質関与成分の分布を調 查することは，今後の種閒雑種を利用した品種改良や， チャの物質代謝特性の解明の基礎となる す̣のと思われ る。

57 年 2 月から 5 月にかけて, 插木養成した 6 節 21 種 (さらに 2 種の接木苗b調查) の第一次伸育葉を採取し， カフェイン・アミノ酸・カテキン類について分析, 検討 した。

カフェインはクロロホルム抽出後, ガスクロマトグラ フィーで分析した。アミノ酸は試料が少量のため，熱湯 抽出後, ダンシル化して高速液体クロマトグラフィーて 分析した。アラニンとアルギニンは分離困難のため, こ の保持時間のピークはアルギニンとして計算した。カテ キン類は酢エチ抽出後, TMS 化してガスクロマトグラ フィーで分析した。

カフェインはチャとタリエンシスの 2 種にのみ検出さ れた。またチャ節 3 種の植物はテアニン含量が $0.2 \%$ 以 上であった。他 5 節ではフルフラセアから微量検出され た以外は，検出限界 (0.01\%) 以下であった。カテキン 類が 5 種とす検出されたのはチャ節 3 種のみで，他 5 節 の種からはエピカテキンガレート・エピガロカテキンガ レートは検出されなかった。したがって，この2種のカ
テキン類とテアニンおよびカフェインの 4 化合物は，カ メリア属の中でもごく一部の種に偏在する特異な物質で あると荌えられる。

チャ節 3 種を比較するとタリエンシスはテアニン含量 は低いが，調查した全成分が存在し，その組成もチャに 近かった。イラワジェンシスは，アミノ酸はタリエンシ スと同様の傾向を示したが，カフェインは検出されず， またカテキン類のうちエピガロカテキンガレートの濃度 が低かった。

エピカテキン，力テキンはツバキの属するカメリア節 やへテロジェニア節に多く，サザンカを含むパラカメリ ア節や他2節には少なかった。また化学異性体のエピカ テキンと(十)カテキン含量を比較するとへテロジェニア 節 2 種とオレイフェラ・ホウザンツバキに (十)カテキン が多く, カテキン類の代謝に他種と差があると推察され る。

カテキン類の ガスクロマトグラムの昇温部にサザンカ の 2 品種とるに認められる未知の 4 ピークが検出され た。他種ではサルウィンツバキ・ホウザンツバキにも検 出されるが，この2種がサザンカとの近縁種であること を示すすのとす考光られ，今後この 4 成分について同定 したい。

\section{1-9 Camellia 属種間雑種における化学成分の変異}

\author{
永田忠博 - 酒井慎介 \\ （譨林水産省茶業試験場）
}

チャと他種の雑種の化学成分を調查し，これら成分の 遺伝様式を解明することは，今後の種間婎種による品種
改良の基䃈資料となる。今回，ツバキ拉よびサザンカを 片親とする種間染種について, カフェイン,アミノ酸, 
カテキン類の分布を調查した。また合せて Camellia 属 の帰属不明種についてす調查した。

チャの種間雑種は，ツバキを花粉親とする 3 個体，ユ キツバキとチャの自然雃種である炬開き，サザンカを母 本とする 4 個体を供試した。炉開きは原木の，他は実生 苗の第 1 次伸青葉を採取し，前報潗じて分析した。

さやまか抢りとツバキの雑種 3 個体は，カフェイン， アミノ酸, カテキン類ともに，母親のチャより少なかっ た。

これに対し，炉開きはカテキン類が多く，特にエピガ ロカテキン，エピカテキン含量が高かった。ツバキを含 むカメリア節は他節に比べエピカテキンあるいは(十)カ テキン含量が高いるのが多く，カテキン類の生成能力の 大きな雑種も生まれるのであろら。化学成分分析の結果 からる炣開きの片親が チャであることは裹付けられた。

チャとサザンカの雑種 4 個体の中には，カフェイン・ エピカテキンをチャと同程度に含むるのああったが，他 成分は少なく，特にアミノ酸含量は全て低かった。また 4 個体とも，サザンカほか 2 種に特異的に検出される末
知の 4 成分が検出された。この 4 成分の有無がサザンカ 雑種とツバキ雑種の化学成分比較の上での 最も大きな差 異であった。

帰属不明種のハルサザンカ，カンツバキ，ワビスケに ついては, 全品種とすカフェイン，テアニン，エピガロ カテキンガレートは検出されなかった。しかし，一部の ワビスケには エピカテキンガレートの保持時間に小ピー クが検出された。

サザンカ等に特異的な未知の 4 ピークはハルサザン カ, カンツバキの計 6 品種全てから検出された。サザン カが交雑しているためと考点られ，ハルサザンカ・カン ツバキがサザンカとツバキの種間雑種といら説を支持す る結果と思われる。

ワビスケはサザンカ，サルウィンツバキ等に特異的な 未知の 4 ピークが検出されず，かつカフェイン等のチャ 特有成分も存在しないことから，ワビスケがチャ，サル ウィンッバキ等の交雑により生じた 可能性は少ないと考 えられた。

\section{$1-10$ 水耕栽培による茶樹品種の生育および 養分吸収の品種間差について（II）}

水耕液の窒素濃度と茶樹品種の生育

岡 野 信 雄

（埼玉県茶業試験場）

前報に引き続いて茶樹品種の栄養特性を知るために， 水耕法に上って 4 品種 2 系統を使い培養液中の空素濃度 をかえて試験した。現在す試験を継続中であるので結果 の一部（1981年の一番茶の収量形質）を紹介する。

試験結果の概要は次のと㧊りである。

(1) 芽数汸て

(1) 分散分析の結果によると, 品種間ならびに処理 間に $5 \%$ 水準で有意な差を認めた。

(2)「こさかげ」のほかは II区の芽数が最も多い傾 向であった。

(3) D検定によって処理ごとに「やぶきた」と比較 してみるとI区では「やぶきた」と有意な差のあ る品種系統はなく，II区では「こ杰かげ」だけが 有意に少なく，亚区では「拉くむさし」，「こ亦か

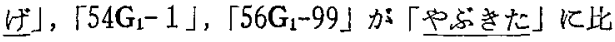
較して有意に少なかった。

(4) 同じくD榆定によって品種ごとに処理聞の差を

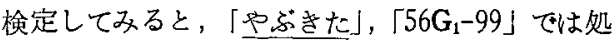
理間には有意な差は認められなかった。「拉くむ

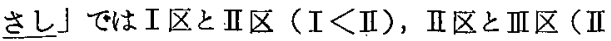

＞III）に有意な差が，「さやまか括り」ではＩ区 と II区（I<II）に有意な差か，「こまかげ」で は各区間（I>II＞III）に有意な差が，「54 $\left.\mathrm{G}_{1}-1\right\rfloor$ ではI区と III区（I＜III），II区とIII区（II >III） に有意な差か認められた。

(2) 芽重について

(1) 分散分析の結果によると，品種間ならびに処理 間に $1 \%$ 水準で有意な差を認めた。

(2)「こまかげ」の潘かは II区の芽重が最り重い傾 向であった。

(3) D検定によって処理ごとにやや゙きたと比較 してみると，II 区で「54G-1」が「やぶきた」 よりも芽重が重く，一方「こまかげ」では軽かっ

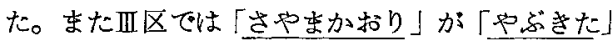
よりも芽重が重く，一方「こ䖢かげ」では軽かっ た。

(4) 同じくD検定によって品種ごとに処理間の差を 検定してみると，「やぶさた」，「拓くむさし」， $\left\lceil 54 \mathrm{G}_{1}-1\right\rfloor,\left\lceil 56 \mathrm{G}_{1}-99\right\rfloor$ では I区と II 区 $(\mathrm{I}<\mathrm{II})$ およびII 区とIII区（II >III）に有意な差を認めた。 